\title{
Effect of Maternal Estradiol Hormone on Gene Expression in Zebrafish (Danio rerio) Embryos and its Clinical Implications
}

\author{
Md. Golam Rabbane ${ }^{1}$ and A. F. M. Arifur Rahman ${ }^{2}$ \\ ${ }^{1}$ Department of Fisheries, University of Dhaka, Dhaka-1000, Bangladesh \\ ${ }^{2}$ Department of Fisheries and Marine Science, Noakhali Science and Technology University, \\ Sonapur, Noakhali, Bangladesh
}

\begin{abstract}
Maternal steroid hormone, estradiol plays significant role in fertilized eggs by performing proper embryo development. The study was performed to observe the genetic effects of estradiol by using reverse transcriptase polymerase chain reaction. A total three steroid responsive genes were analysed namely anx2a, ccng1 and hmox1. The ef1a gene was used as reference to normalize data. The transcripts of anx2a were down regulated in E2 0.01 treated embryos at $8 \mathrm{hpf}$ when compared to contol and E2 0.1 treated embryos. The ccng1 transcripts for E2 0.1 and E2 0.01 and E2 treated embryos were equally and strongly expressed. There was also no up or downregulation when analysed with hmox1 gene. So the results suggest that different estradiol concentrations can alter specific genetic expression at $8 \mathrm{hpf}$ embryonic state and clinically it could be used as an effective gene therapy. However, extensive studies should be conducted to assess its beneficial effects on human being.
\end{abstract}

Key words: Gene expression, Estradiol hormone, Zebrafish, Clinical implications

\section{INTRODUCTION}

In teleost fish like other oviparous vertebrates, the yolk of ovulated eggs contain significant amount of liposoluble hormones such as thyroid, steroid and retinoid etc. These hormones are taken up from either maternal circulation or follicular envelopes. ${ }^{1,2}$ This store of maternal hormones may accomplish the regulatory requirements of larvae for growth, development, osmoregulation, stress responses and other physiological functions prior to the functional development of their own endocrine glands. ${ }^{3}$

Experiments on some fish species have shown that hormones especially maternal steroid hormones play important role in larval development and thus may affect egg quality. ${ }^{4}$ For example, several sex steroids have been reported to be present in fertilized eggs of tilapia and salmonids, cortisol in Mozambique tilapia (Oreochromis mossambicus) and

Correspondence to: Md. Golam Rabbane Cell: 0088-01818229810

E-mail: rabbane_du@yahoo.com

Dhaka Univ. J. Pharm. Sci. 12(2): 147-151, 2013 (December) testosterone in medaka (Oryzias latipes). ${ }^{5-8}$ In addition, dynamic changes in cortisol content profile were reported in tilapia and zebrafish, showing a steady decline from fertilization until hatching in both species. ${ }^{9,10}$

Estradiol or $17 \beta$-estradiol is an important sex hormone. Estradiol is abbreviated E2 as it has two hydroxyl groups in its molecular structure. E2 has not only a critical impact on reproductive and sexual functioning, but also affects other organs, including the bones. So the studies was undertaken to investigate the genetic effects of estradiol on fertilized zebrafish eggs.

\section{MATERIALS AND METHODS}

Breeding and treatment. Natural breeding was performed to obtain fertilized eggs with $28.5^{\circ} \mathrm{C}$ water temperature and with a photoperiod of $14 \mathrm{~h}$ light and $10 \mathrm{~h}$ dark. Immediately after fertilization, fertilized eggs were pooled in estradiol $(0.1 \mathrm{mg} / \mathrm{l}$ and 0.01 $\mathrm{mg} / \mathrm{l})$, and abs EtOH $(1 \mathrm{mg} / \mathrm{l})$ solutions for $2 \mathrm{~h}$ for development and fixation up to 8 hours post 
fertilization (hpf). After $2 \mathrm{~h}$ of treatment, the estradiol and $\mathrm{EtOH}$ treatment solution was poured out and eggs were gently washed 5-fold in fish water to eliminate any trace of estradiol and ethanol.

RNA isolation. To evaluate gene expression, total RNA was extracted from pools of about 60 embryos at $8 \mathrm{hpf}$ developmental stages using TRIZOL reagent, according to the manufacturer's instructions (Invitrogen, Milan, Italy). The experimental phase of extraction and manipulation was carried out under a chemical hood using sterile glassware or sterilized at $200^{\circ} \mathrm{C}$ in oven for the entire night. The isolated RNA samples were stored at $-80^{\circ} \mathrm{C}$ until future use.

RNA and cDNA samples, obtained from embryos and PCR (Polymerase Chain Reaction) reactions were analysed by agarose (Fisher Molecular Biology, USA) gel electrophoresis. This was carried out until the marker dye (bromophenol blue, added to the sample prior to loading) reaches the end of the gel. The nucleic acids in the gel are visualised by staining with the intercalating dye gel red and examined under ultraviolet light.

Quantification of total RNA. The concentration of total RNA was measured by NanoDrop Spectrophotometer (Celbio, Milan, Italy), which allows an assessment of the state of purity or protein contamination. The concentration of $1.5 \mu \mathrm{l}$ solution of nucleic acid was determined by measuring the absorbance at $260 \mathrm{~nm}$. An $\mathrm{A}_{260}$ of 1.0 is equivalent to a concentration of $50 \mu \mathrm{g} / \mathrm{ml}$ for double-stranded DNA, or $40 \mu \mathrm{g} / \mathrm{ml}$ for single-stranded DNA or RNA. The $\mathrm{A}_{260} / \mathrm{A}_{280}$ ratio should be 1.8 for pure DNA and 2.0 for pure RNA preparations. ${ }^{11}$
Reverse transcription of RNA. After quantification of extracted RNA, reverse transcription was performed using Moloney Murine Leukemia Virus Reverse Transcriptase (M-MLV RT) protocol (Invitrogen), according to the manufacturer's instructions. M-MLV RT uses single-stranded RNA or DNA in the presence of a primer to synthesize a complementary DNA strand.

The M-MLV RT PCR is a two-step process. Briefly, $2 \mu \mathrm{g}$ of the purified total RNA was mixed with random hexamer and pure water to a final volume of $10 \mu \mathrm{l}$, denatured by incubation at $70^{\circ} \mathrm{C}$ for $5 \mathrm{~min}$ and then placed on ice for $5 \mathrm{~min}$. Then, $15 \mu \mathrm{l}$ of cDNA synthesis Buffer (5X), dNTP Mix (10 mM), M-MLV reverse transcriptase enzyme and $\mathrm{H}_{2} \mathrm{O}$ were added to each sample. The samples were incubated in a PCR machine at $25^{\circ} \mathrm{C}$ for $10 \mathrm{~min}, 50^{\circ} \mathrm{C}$ for $50 \mathrm{~min}$ and $70^{\circ} \mathrm{C}$ for $15 \mathrm{~min}$. Then, the cDNA reactions were either stored at $-20^{\circ} \mathrm{C}$ or used for PCR immediately.

Touchdown PCR. Total cDNA (200 ng) was amplified by PCR containing $4 \mu$ of ImProm-II ${ }^{\text {TM }} 5 \mathrm{X}$ Reaction Buffer, $2.4 \mu \mathrm{l}$ of $\mathrm{MgCl}_{2}, 1 \mu \mathrm{l}$ of dNTP mix, $0.5 \mu \mathrm{l}$ of Recombinant RNasin ${ }^{\circledR}$ Ribonuclease Inhibitor, $0.5 \mu \mathrm{l}$ of the respective primers, $1 \mu \mathrm{l}$ ImProm-II ${ }^{\mathrm{TM}}$ Reverse Transcriptase and ultrapure water to a final volume of $10 \mu \mathrm{l}$. The melting point of the primer sets the upper limit on annealing temperature. The annealing temperature of the initial cycle is $5-10^{\circ} \mathrm{C}$ above the melting temperature of the primers and the temperature is gradually reduced by $1{ }^{\circ} \mathrm{C}$ for each following cycle down to the lowest melting temperature value of the primer. PCR products for each gene of interest were sequenced to confirm amplicon identity. The list of primers are shown in Table 1.

Table 1. List of primers

\begin{tabular}{lllll}
\hline Primer & Orientation & \multicolumn{1}{c}{ Sequence } & Position & Accession number \\
\hline ef1a-F & Sense & 5'-GACAAGAGAACCATCGAG-3' & $+177 \rightarrow+194$ & NM_131263 \\
ef1a-R & Antisense & 5'-CCTCAAACTCACCGACAC-3' & $+447 \rightarrow+430$ & \\
ccng1-F & Sense & 5'-GATTGAGGATCAGCACGAG-3' & $+804 \rightarrow+822$ & NM_199481 \\
ccng1-R & Antisense & 5'-CAGTTATGGGCACTCAACAC-3' & $+1099 \rightarrow+1080$ & \\
anx2a-F & Sense & 5'-GCACAGATGTGAAGTGCTG-3' & $+646 \rightarrow+664$ & NM_181761 \\
anx2a-R & Antisense & 5' -CAGTCGTCTCCATTGCAC-3' & $+1059 \rightarrow+1042$ & \\
hmox1-F & Sense & 5'-CCACACACCGATATGCAC-3' & $+582 \rightarrow+599$ & NM_00127516 \\
hmox1-R & Antisense & 5' -CAACGTGATGCCCACTCC-3' & $+1030 \rightarrow+1013$ & \\
\hline
\end{tabular}




\section{RESULTS AND DISCUSSIONS}

The quality of RNA was identified by running the extracted RNA samples through agarose gel electrophoresis by indicating two bands: an upper $28 \mathrm{~S}$ rRNA and a lower 18S rRNA (Figure 1). So the quality of extracted RNA was found good due to the absence of additional bands or smear.

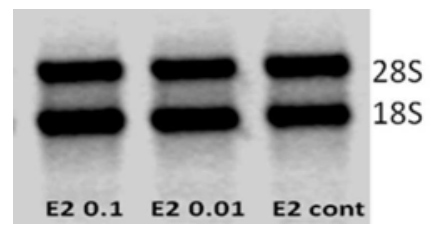

Figure 1. Separation of total RNA on denaturing gel electrophoresis followed by gel red staining.

The quantification results of extracted RNA is shown in table 2 where E2 0.01 and E2 0.1 received higher concentration 746.47 and $574.99 \mathrm{ng} / \mu \mathrm{l}$ respectively. But lower concentration observed $314.23 \mathrm{ng} / \mu 1$ in E2 control sample. Samples E2 0.01 and E2 control obtained pure quality RNA because $\mathrm{A}_{260} / \mathrm{A}_{280}$ was greater than 2. ${ }^{11}$

To determine the effects of estradiol on gene expression during first developmental stage, a total three genes were selected namely annexin $A 2 a$ (anx2a), cyclin G1 (ccng1) and heme oxygenase (decycling)1 (hmox1). The touchdown PCR analysis revealed that the transcripts of anx2a were poorly expressed in E2 0.01 treated embryos when compared to control and E2 0.1 treated embryos as shown in Figure 2. But there was no $a n x 2 a$ transcripts different between E2 0.1 and control

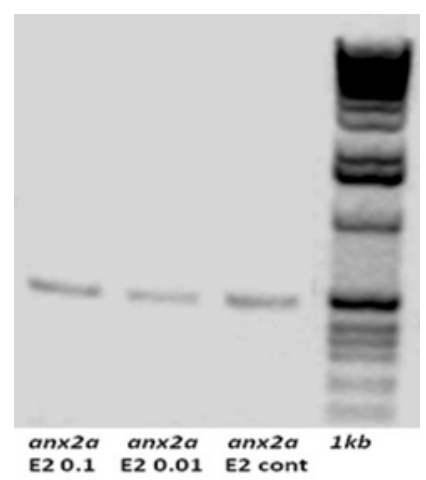

Figure 2. Expression of anx2a transcripts during $8 \mathrm{hpf}$ developmental stage of zebrafish. embryos. It may be assumed that biological mechanisms can influence the regulation of anx $2 \mathrm{a}$ transcripts with changing the amount of E2. This messenger was up-regulated when embryos were knocked down with MO2-esr2a. ${ }^{12}$ anx2a plays vital role as calcium ion binding, calcium-dependent phospholipid binding and cytoskeletal protein binding. ${ }^{12-14}$ So these binding capacities could be reduced by down-regulating anx2a gene expression. ccng1 transcripts for all treatments were strongly and equally expressed at $8 \mathrm{hpf}$ stage embryos (Figure 3 ). The transcript of cyclin G1 (ccng1), that encodes a protein with intrinsic growth inhibitory activity, was found to be up-regulated at $48 \mathrm{hpf}$ when knocked down with MO2-esr2a. ${ }^{12,15}$

Table 2. Quantification of extracted RNA by NanoDrop Spectrophotometer.

\begin{tabular}{llll}
\hline Sample ID & $\mathrm{ng} / \mu 1$ & $\mathrm{~A}_{260}$ & $\mathrm{~A}_{260} / \mathrm{A}_{280}$ \\
\hline E2 0.1 & 574.99 & 14.3 & 1.97 \\
E2 0.01 & 746.47 & 18.6 & 2.04 \\
E2 cont. & 314.23 & 7.8 & 2.04 \\
\hline
\end{tabular}

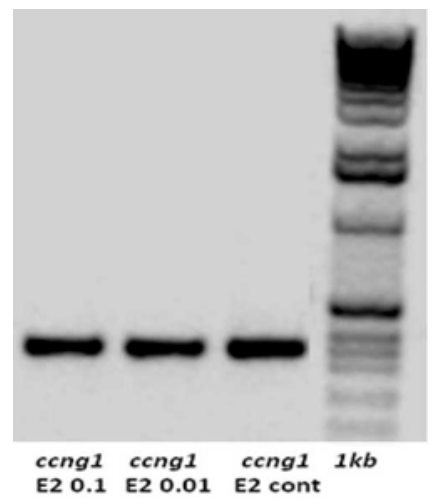

Figure 3. Expression of ccng 1 transcripts during $8 \mathrm{hpf}$ developmental stage of zebrafish.

Finally, the expression of heme oxygenase (decycling)1 (hmox1) transcripts were analysed to determine the effects of estradiol. Hmox 1 encodes a protein that in mammals, catabolizes heme to biliverdin, carbon monoxide, and free iron and is involved in iron homeostasis. ${ }^{16}$ In zebrafish, this gene is expressed in the extraembryonic yolk syncytial layer, lens, and a small population of blood cells. ${ }^{17}$ There was no up or down-regulation when 
analysed with hmox1 gene (Figure 4). Significant down-regulation of hmox 1 transcripts by RT-PCR at 8 and 48 hpf developmental stages when knocked down with MO2-esr2a. ${ }^{12}$ Estradiol has been attached to the expansion and progression of cancers such as ovarian cancer and endometrial cancer. Estradiol effects target tissues by interacting with estrogen receptors. These estrogen receptors are involved in gene expression. ${ }^{18}$ When hormone binds to the estrogen receptors, it possibly causes damage to the DNA, increase in cell proliferation and DNA replication. ${ }^{19}$

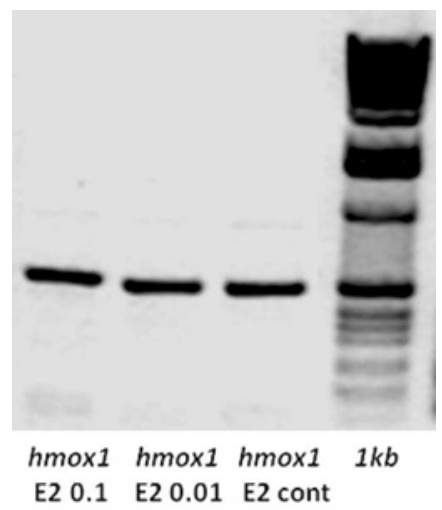

Figure 4. Expression of hmox 1 transcripts during $8 \mathrm{hpf}$ developmental stage of zebrafish.

The present report reveals that oocyte estradiol concentration can change genetic expression at different developmental stages in zebrafish. So a powerful regulatory control linked to maternal experience in terms of estradiol can be directly transmitted into lineage before their actual sensing of surrounding environmental cues. In this way estradiol transcripts in oocyte may expect an epigenetic plasticity in zebrafish development, as a maternal contribution to the adaptive value of the progeny.

\section{ACKNOWLEDGEMENT}

The authors would like to thank Prof. L. Colombo, Dr. L.D. Valle and Dr. F. Benato for their kind assistance to conduct this study.

\section{REFERENCES}

1. McCormick, M.I. 1999. Experimental test of the effect of maternal hormones on larval quality of a coral reef fish. Oecologia 118, 412-422.
2. Irie, T. and Seki, T. 2002. Retinoid composition and retinal localization in the eggs of teleost fishes. Comp. Biochem. Physiol. Biochem. Mol. Biol. 131, 209-219.

3. Lam, T.J. 1994. Hormones and egg larval quality in fish. $J$. World Aquaculture Society. 25, 2-12.

4. Brooks, S., Tyler, C.R. and Sumpter, J.P. 1997. Egg quality in fish: what makes a good egg? Rev. Fish Biol. Fish. 7, 387-416.

5. Rothbard, S., Moav, B. and Yaron, Z. 1987. Changes in steroid concentrations during sexual ontogenesis in tilapia. Aquaculture 61, 59-74.

6. Feist, G., Schreck, C.B., Fitzpatrick, M.S. and Redding, J.M. 1990. Sex steroid profiles of coho salmon (Oncorhynchus kisutch) during early development and sexual differentiation. Gen. Comp. Endocrinol. 80, 299-313.

7. Shiraishi, K., Matsuda, M., Mori, T. and Hirano, T. 1999. Changes in expression of prolactin- and cortisol-receptor genes during early-life stages of euryhaline tilapia (Oreochromis mossambicus) in fresh water and seawater. Zool. Sci. 16, 139-146.

8. Iwamatsu, T., Kobayashi, H., Sagegami, R. and Shuo, T. 2006. Testosterone content of developing eggs and sex reversal in the medaka (Oryzias latipes). Gen. Comp. Endocrinol. 145, 67-74.

9. Hwang, P.P., Wu, S.M., Lin, J.H. and Wu, L.S. 1992. Cortisol content of eggs and larvae of teleosts. Gen. Comp. Endocrinol. 86, 189-196.

10. Aslop, D. and Vijayan, M.M. 2008. Development of the corticosteroid stress axis and receptor expression in zebrafish. Am. J. Physiol. Regul. Integr. Comp. Physiol. 294, R711-R719.

11. Nicholl, D.S.T. 1996. An introduction to genetic engineering. Cambridge University Press, p. 23.

12. Celeghin, A., Benato, F., Pikulkaew, P., Rabbane, M.G., Colombo, L. and Dalla Valle, L. 2011.The knockdown of the maternal estrogen receptor $2 \mathrm{a}$ (esr2a) mRNA affects embryo transcript contents and larval development in zebrafish. Gen. Comp. Endocrinol. 172, 120-129.

13. Singh, S.K., Sundaram, C.S., Shanbhag, S. and Idris, M.M. 2010. Proteomic profile of zebrafish brain based on twodimensional gel electrophoresis matrix-assisted laser desorption/ionization ms/ms analysis. Zebrafish 7, 169-177

14. Xiong, X.P., Dong, C.F., Xu, X., Weng, S.P., Liu, Z.Y. and $\mathrm{He}_{2} \mathrm{~J}_{-} \mathrm{G} .2011$. Proteomic analysis of zebrafish (Danio rerio) infected with infectious spleen and kidney necrosis virus. Dev. Comp. Immunol. 35, 431-440.

15. Zhao, L., Samuels, T., Winckler, S., Korgaonkar, C., Tompkins, V., Horne, M.C. and Quelle, D.E. 2003. Cyclin G1 has growth inhibitory activity linked to the ARF-Mdm2p53 and pRb tumor suppressor pathways. Mol. Cancer Res. 1, 195-206. 
16. Poss, K.D. and Tonegawa, S. 1997. Heme oxygenase 1 is required for mammalian iron reutilization. Proc. Natl. Acad. Sci. 94, 10919-10924.

17. Thisse, B. and Thisse, C. 2004. Fast Release Clones: A High Throughput Expression Analysis. ZFIN Direct Data Submission. (http://zfin.org).

18. Sreeja, S. Kumar, T. Lakshmi, B. and Sreeja, S. 2012. Pomegranate extract demonstrate a selective estrogen receptor modulator profile in human tumor cell lines and in vivo models of estrogen deprivation. J. Nutr. Biochem. 23, 725-32.
19. Christoforos, T. Strom, A. Lindberg, K. and Gustafsson, J. 2011. Estrogen receptor beta decreases survival of p53defective cancer cells after DNA damage by impairing G2/M checkpoint signaling. Breast Cancer Res. Treat. 127, 417427. 